\title{
Effect of ultraviolet light on water- and fat-soluble vitamins in cow and goat milk
}

\author{
O. Guneser and Y. Karagul Yuceer ${ }^{1}$ \\ Faculty of Engineering-Architecture, Department of Food Engineering Canakkale Onsekiz Mart University, Terzioglu Campus, \\ 17020 Canakkale, Turkey
}

\begin{abstract}
The objective of this study was to investigate and compare the effects of UV light and heat treatment on vitamins $\mathrm{A}, \mathrm{B}_{2}, \mathrm{C}$, and $\mathrm{E}$ in cow and goat milk. Vitamins were analyzed by reverse-phase high-pressure liquid chromatography. Ultraviolet and pasteurization treatments caused loss in vitamin $\mathrm{C}$ in milk. Pasteurization did not have any significant effect on vitamin $\mathrm{B}_{2}$. However, UV light treatment decreased the amount of vitamin $\mathrm{B}_{2}$ after several passes of milk through the UV system. In addition, UV light treatment decreased the amount of vitamins $\mathrm{A}$ and $\mathrm{E}$. Vitamins $\mathrm{C}$ and $\mathrm{E}$ are more sensitive to UV light. UV light sensitivities of vitamins were $\mathrm{C}>\mathrm{E}>\mathrm{A}>\mathrm{B}_{2}$. These results show that UV light treatment decreases the vitamin content in milk. Also, the number of passes through the UV system and the initial amount of vitamins in milk are important factors affecting vitamin levels.
\end{abstract}

Key words: ultraviolet light, fat- and water-soluble vitamins, cow milk, goat milk

\section{INTRODUCTION}

For the production of milk and dairy products, heat treatment is the most common process to inhibit the growth of pathogens and spoilage microorganisms and to inactivate enzymes in milk. Three types of heat treatment to milk include thermization, pasteurization, and sterilization in the dairy industry (Raynal-Ljutovac et al., 2007). Pasteurization is widely used as a thermal process for milk. In pasteurization, milk is heated to $63^{\circ} \mathrm{C}$ for $30 \mathrm{~min}$ (low temperature, long time) or to $72^{\circ} \mathrm{C}$ for $15 \mathrm{~s}$ (HTST; Fox and McSweeney, 1998). Physical, chemical, and sensorial changes may occur during heat treatment of milk. Although some changes are favorable, others are considered undesirable, because they

Received December 25, 2011.

Accepted February 4, 2012.

${ }^{1}$ Corresponding author: yoncayuceer@comu.edu.tr cause adverse effects on sensory characteristics, nutritional values, and technological properties of milk (Fox and McSweeney, 1998; Lewis, 2003).

A loss of water- and fat-soluble vitamins in milk during the heating process has been reported (Holmes et al., 1945; Lavigne et al., 1989; Oamen et al., 1989; Sierra and Vidal-Valverde, 2001; Bendicho et al., 2002; Asadullah et al., 2010; Moltó-Puigmartí et al., 2011). Holmes et al. (1945) reported that HTST pasteurization $\left(71-83^{\circ} \mathrm{C}, 22 \mathrm{~s}\right)$ of raw milk results in 18.7 and $3 \%$ of losses of vitamin $\mathrm{C}$ and $\mathrm{B}_{1}$ (thiamin), respectively. No change to vitamin $B_{2}$ (riboflavin) content was observed. Lavigne et al. (1989) evaluated different pasteurization and sterilization processes in terms of changes to vitamins $\mathrm{B}_{1}, \mathrm{~B}_{2}$, and $\mathrm{C}$ content in goat milk. Low-temperature, long-time (LTLT; $63.5^{\circ} \mathrm{C}$ for $30 \mathrm{~min})$, HTST $\left(76^{\circ} \mathrm{C}\right.$ for $\left.16 \mathrm{~s}\right)$, UHT $\left(135^{\circ} \mathrm{C}\right.$ for $\left.4 \mathrm{~s}\right)$, and sterilization $\left(121^{\circ} \mathrm{C}\right.$ for $\left.15 \mathrm{~min}\right)$ decreased the vitamin $\mathrm{C}$ level in goat milk at the rate of $40,25,30$, and $70 \%$, respectively. No significant decrease in vitamin $B_{2}$ content by HTST and UHT processing was observed. However, LTLT and sterilization decreased vitamin $\mathrm{B}_{2}$ content by 20 and $30 \%$, respectively. Asadullah et al. (2010) reported that household heating of milk (boiling about $100^{\circ} \mathrm{C}$ for $15 \mathrm{~min}$ ) causes $27,27,29,24$, and $36.2 \%$ loss in vitamins $\mathrm{B}_{1}, \mathrm{~B}_{2}, \mathrm{~B}_{3}, \mathrm{~B}_{6}$, and folic acid, respectively. Moltó-Puigmartí et al. (2011) investigated effects of LTLT pasteurization and high-pressure processing on ascorbic acid (vitamin $\mathrm{C}$ ) and $\alpha$ - and $\delta$-tocopherol isomers (vitamin E) in human milk. Lowtemperature, long-time processing reduced vitamin $\mathrm{C}$ and $\alpha$ - and $\delta$-tocopherol isomers in human milk at rates of 16.2, 0.97, and 2.08\%, respectively. High-pressure processing did not significantly affect ascorbic acid and tocopherol levels.

Today, increasing consumer preference for high nutritional and quality food products have led to the development of novel techniques to process dairy products. Ultraviolet light treatment has commercial potential among nonthermal food technologies as an alternative to heat treatment (pasteurization) of liquid foods (Bintsis et al., 2000; Lopez-Malo and Palou, 2005; Koutchma, 2009). Ultraviolet light has been used for 
disinfection of surfaces, air, water, and equipment for over $60 \mathrm{yr}$. The UV light spectrum ranges from 100 to $400 \mathrm{~nm}$. The range of 200 to $280 \mathrm{~nm}$ UV light spectrum (UV-C) has a germicidal effect on microorganisms, including bacteria, yeasts, molds, and viruses. Microbial inactivation in liquid foods by UV-C depends on optical and flow properties of the product, microbial load of the product, geometric configuration of the reactor, power, wavelength and physical arrangement of the UV source(s), and radiation path length (Koutchma et al., 2009). These critical factors of UV treatments for liquid food processing are discussed by Koutchma et al. (2009).

Several studies have been conducted on determining the effects of UV treatment on microbiological, physicochemical and sensory properties of clear liquid foods, such as fruit juices (Gachovska et al., 2008; Keyser et al., 2008; Franz et al., 2009; Guerrero-Beltrán et al., 2009; Fredericks et al., 2011; Uysal Pala and Kirca Toklucu, 2011; Caminiti et al., 2012). However, only a limited number of studies have been done on UV light applications in opaque liquid foods such as milk and liquid dairy products. Although UV light influence on pathogens and indicator microorganisms in milk has been a particular focus in these studies (Smith et al., 2002; Matak et al., 2005; Reinemann et al., 2006; Altic et al., 2007; Donaghy et al., 2009; Engin et al., 2009), its effects on nutritional properties of milk have not been assessed. Therefore, the aims of this research were to determine the effects of UV light and pasteurization on vitamins $\mathrm{C}, \mathrm{B}_{2}, \mathrm{~A}$, and $\mathrm{E}$ and to compare the vitamin losses by pasteurization and UV light treatment in milk from cows and goats.

\section{MATERIALS AND METHODS}

\section{Milk}

Goat milk samples $(\mathrm{n}=3)$ were obtained from the Turkish Saanen breed in the late-lactation period (October 2010 to April 2011) at Canakkale Onsekiz Mart University-Technological and Agricultural Research Center (Canakkale, Turkey). Cow milk samples $(\mathrm{n}=4)$ were obtained from local producers (May-July 2011) in Canakkale. One of the cow milk samples (C4) was used for the manipulation experiment. Milk samples were carried in thermo bag with an ice pack at $10^{\circ} \mathrm{C}$ and analyzed immediately in our laboratory.

\section{Pasteurization}

Milk samples were pasteurized in a 1-L glass jar in a thermostatic water bath [Gesellschaft für Labortechnik
(GFL) $\mathrm{mbH}$, Großburgwedel, Germany] at $65^{\circ} \mathrm{C}$ for 30 $\min$.

\section{UV Light Treatment}

A custom-made UV light system equipped with 9 UV-C type lamps (Gentra Stock Joint Co., Istanbul, Turkey) was used for UV treatment of milk (Engin and Karagul Yuceer, 2012). The UV reactor was designed by Yusuf Köprülü (Gentra Insaat ve Ticaret Ltd. Sti., Istanbul, Turkey). The UV unit consists of a stainless steel reflector, a corrugated Teflon tube coiled around quartz sleeve and $9 \mathrm{UV}$ lamps $(254 \mathrm{~nm} ; 28 \mathrm{~W}$ UV-C output; the length of each lamp was $842.4 \mathrm{~mm}$ and the diameter was $16 \mathrm{~mm}$ ). The UV light intensity per single pass through the reactor was calculated based on the flow rate of milk through the reactor and total output wattage of UV lamps (Engin and Karagul Yuceer, 2012) by using Equation 1, suggested by Geveke (2008) and Keyser et al. (2008):

$$
\begin{gathered}
\mathrm{UV} \text { intensity }(\mathrm{J} / \mathrm{mL})=\text { total } \mathrm{UV}-\mathrm{C} \text { output } \\
\text { power }(\mathrm{W}) / \text { flow rate }(\mathrm{mL} / \mathrm{s}) .
\end{gathered}
$$

Seven passes were applied to milk in the reactor to evaluate changes to vitamin content under UV light. Vitamin analysis was conducted after $1,3,5$, and 7 passes. The beginning temperature of the milk was $18^{\circ} \mathrm{C}$ and was raised to $25^{\circ} \mathrm{C}$ after 7 passes through the system. The UV light intensities applied to milk samples are shown in Table 1.

\section{Composition of Milk}

The titratable acidity (lactic acid, \%), $\mathrm{pH}$, and DM $(\%)$, total protein (\%), and ash (\%) contents of the milk samples were determined according to procedures described by Bradley et al. (1992). The fat content of the milk samples was determined using a method by Gerber-Van Gulik (NEN, 1969).

Table 1. Ultraviolet light intensity applied to cow and goat milk

\begin{tabular}{lcc}
\hline & \multicolumn{2}{c}{ UV intensity $(\mathrm{J} / \mathrm{mL}$ of milk $)$} \\
\cline { 2 - 3 } UV treatment & Cow milk & Goat milk \\
\hline First pass & 12.6 & 11.72 \\
Third pass & 37.8 & 35.16 \\
Fifth pass & 63.0 & 58.60 \\
Seventh pass & 88.2 & 82.04 \\
\hline
\end{tabular}




\section{Water-Soluble Vitamins}

Determination of Vitamin $C$ Content. The ascorbic acid content of milk samples was determined by using the HPLC method of Romeu-Nadal et al. (2006) with minor modifications. Five milliliters of milk and $5 \mathrm{~mL}$ of metaphosphoric acid $(5.6 \%)$ were poured into a $15-\mathrm{mL}$ Falcon tube. The mixture was vortexed for $1 \mathrm{~min}$ in a dark room and centrifuged (2-12 K; Sigma, Göttingen, Germany) for $15 \mathrm{~min}$ at 1,000 $\times g$ at $10^{\circ} \mathrm{C}$. Then, the clear liquid phase was filtered through $0.45-\mu \mathrm{m}$ polytetrafluoroethylene (PTFE) filter and $5 \mu \mathrm{L}$ of filtrate was directly injected into the HPLC system. Separation of ascorbic acid in milk was conducted using the Agilent 1200 series HPLC system and Agilent LiCrospher RP 60 Select B $(5-\mu \mathrm{m})$ column (Agilent Technologies Inc., Folsom, CA) The mobile phases were acetic acid $(0.1 \%, \mathrm{vol} / \mathrm{vol})$ in water and methanol $(95: 5)$. The eluent flow rate was isocratic 0.7 $\mathrm{mL} / \mathrm{min}$ and the column temperature was $25^{\circ} \mathrm{C}$. Vitamin $\mathrm{C}$ was identified by comparison of retention time of pure vitamin C standard at $254 \mathrm{~nm}$. Quantification of vitamin $\mathrm{C}$ in cow milk was conducted using the external standard method, whereas that in goat milk was achieved by the addition method due to peak interactions with other substances in the chromatogram. The repeatability of the method was 0.56 relative standard deviation (RSD\%). For measuring vitamin $\mathrm{C}$ in cow milk, the limit of detection (LOD) and limit of quantification (LOQ) were $0.27 / \mu \mathrm{g} \mathrm{mL}$ and $0.82 \mu \mathrm{g} / \mathrm{mL}$, respectively. The recovery was $107.2 \%$ for vitamin C. Standard and sample chromatograms for vitamin C are shown in Figure 1.

Determination of Vitamin $B_{2}$ Content. The vitamin $\mathrm{B}_{2}$ content of milk samples was determined using the HPLC method of Muñoz et al., (1994), with minor modifications. For sample preparation, $25 \mathrm{~mL}$ of milk was poured into a $50-\mathrm{mL}$ Falcon tube; $2.5 \mathrm{~mL}$ of lead acetate solution (10\%, pH adjusted to 3.2 using glacial acetic acid) was added, and the mixture was vortexed for $3 \mathrm{~min}$ and centrifuged (2-12 K; Sigma) for $15 \mathrm{~min}$ at $8,600 \times g$ at $4^{\circ} \mathrm{C}$. The clear liquid phase was filtered through a $0.22-\mu \mathrm{m}$ PTFE filter, and $10 \mu \mathrm{L}$ of filtrate was directly injected into the HPLC system. All samples were prepared in a dark room to eliminate the effects of light. The mobile phase contained water-acetic acid (1.5 mL of acetic acid in $1 \mathrm{~L}$ of water) and methanol (60:40). The flow rate was $0.6 \mathrm{~mL} / \mathrm{min}$. Ultraviolet detection was at $270 \mathrm{~nm}$, and the column temperature was $20^{\circ} \mathrm{C}$. Riboflavin was identified by comparing the retention time of riboflavin standard provided and quantified using external standard methods. The repeatability of the method was 0.39 (RSD\%). The LOD and LOQ were $0.01 \mu \mathrm{g} / \mathrm{mL}$ and $0.18 \mu \mathrm{g} / \mathrm{mL}$, respectively. The recovery was $102.84 \%$ for vitamin $B_{2}$. Standard and sample chromatograms for vitamin $\mathrm{B}_{2}$ are shown in Figure 1.

\section{Fat-Soluble Vitamins}

Determination of Vitamin $A$ and $E$ Content. Vitamins A and E in milk were extracted using the liquid-liquid extraction method suggested by Zahar and Smith (1990) and modified by Kondyli et al., (2007). Two milliliters of milk was poured into a 50-mL Falcon tube, and $5 \mathrm{~mL}$ of absolute ethanol (include $0.1 \%$ ascorbic acid) and $2 \mathrm{~mL}$ of $50 \%$ (wt/vol) $\mathrm{KOH}$ were added. Following a 2-min vortexing, the tube was placed in a water bath (GFL $\mathrm{GmbH}$ ) for saponification at $80^{\circ} \mathrm{C}$ for $20 \mathrm{~min}$. Then, the tube was cooled. Ten milliliters of petroleum ether:diethyl ether mixture (1:1) containing $0.01 \%$ butylated hydroxytoluene was added. The tube was vortexed for $1 \mathrm{~min}$ and allowed to stand for $2 \mathrm{~min}$. Then, $10 \mathrm{~mL}$ of petroleum ether:diethyl ether mixture was added. The tube was vortexed for $2 \mathrm{~min}$ and allowed to stand for 5 min. Fifteen milliliters of cold water $\left(+4^{\circ} \mathrm{C}\right)$ was added to the tube, which was then shaken to disperse the content. The tube was centrifuged at 2,000 $\times g$ for $15 \mathrm{~min}$. The upper phase was transferred into a $25-\mathrm{mL}$ rotary evaporating flask and the solvent was removed under vacuum at $40^{\circ} \mathrm{C}$ using a rotary evaporator (Heidolph Instruments $\mathrm{GmbH} \& \mathrm{Co}$. KG, Schwabach, Germany). The residue was dissolved in $1 \mathrm{~mL}$ of methanol. The extract was filtered through a $0.45-\mu \mathrm{m}$ PTFE filter and collected in an amber vial (Zahar and Smith, 1990; Kondyli et al., 2007). Injection volumes of the extracts were 25 and $50 \mu \mathrm{L}$ for vitamin E and A, respectively. Separation of vitamins E and A in milk was conducted using the Agilent 1200 series HPLC system and Agilent Zorbax Eclipse XDB C18 column $(5 \mu, 4.6 \mathrm{~mm} \times 150 \mathrm{~mm}$; Agilent Technologies Inc.) at $30^{\circ} \mathrm{C}$. Methanol $(100 \%)$ at a flow rate of 1.0 $\mathrm{mL} / \mathrm{min}$ was used as a mobile phase for the separation of vitamin E. Ultraviolet detection was performed at $292 \mathrm{~nm}$. For vitamin A, the mobile phases were water and methanol (90:10) and the flow rate was $1.2 \mathrm{~mL} /$ min. Ultraviolet detection was performed at $323 \mathrm{~nm}$. Vitamins $\mathrm{A}$ and $\mathrm{E}$ were identified by comparing retention times of their standards and quantified using the external standards methods. Repeatability for vitamin A method was 0.18 (RSD\%). The LOD and LOQ were 0.76 and $2.31 \mu \mathrm{g} / \mathrm{mL}$, respectively. The repeatability for the vitamin $\mathrm{E}$ method was 0.18 (RSD\%) and the LOD and LOQ were 0.88 and $2.67 \mu \mathrm{g} / \mathrm{mL}$, respectively. The recovery was $82.07 \%$ for vitamin $\mathrm{A}$ and $81.86 \%$ for vitamin E. Standard and sample chromatograms of vitamins $\mathrm{A}$ and $\mathrm{E}$ are shown in Figures 2a and 2b, respectively. 
a) Vitamin C Standard

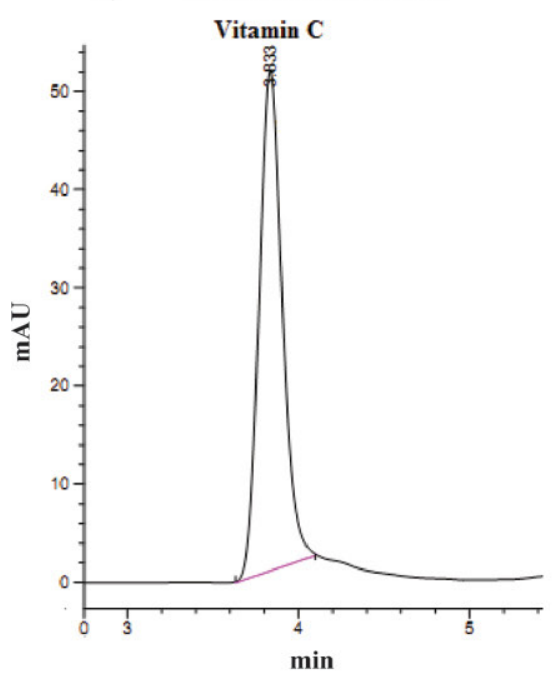

Raw Goat Milk (G1)

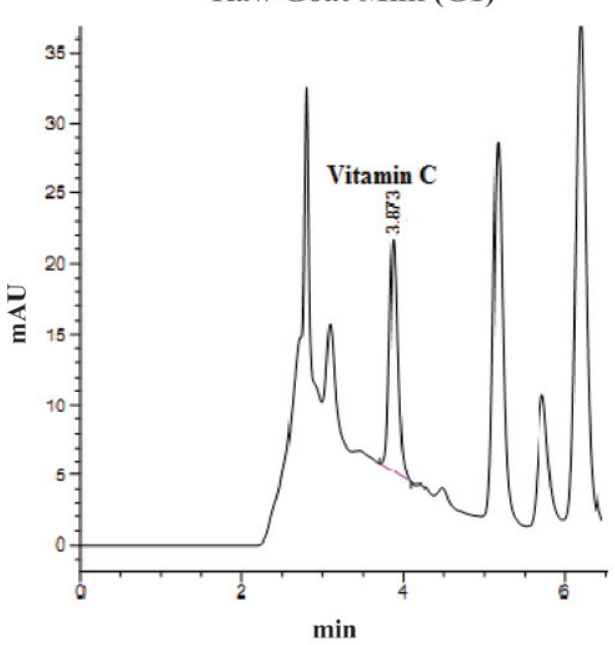

Raw Cow Milk (C1)

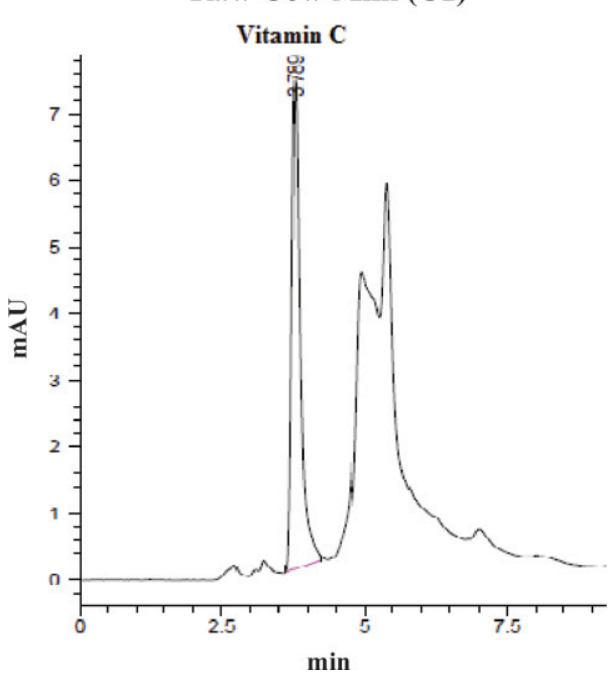

b) Vitamin B2 Standard
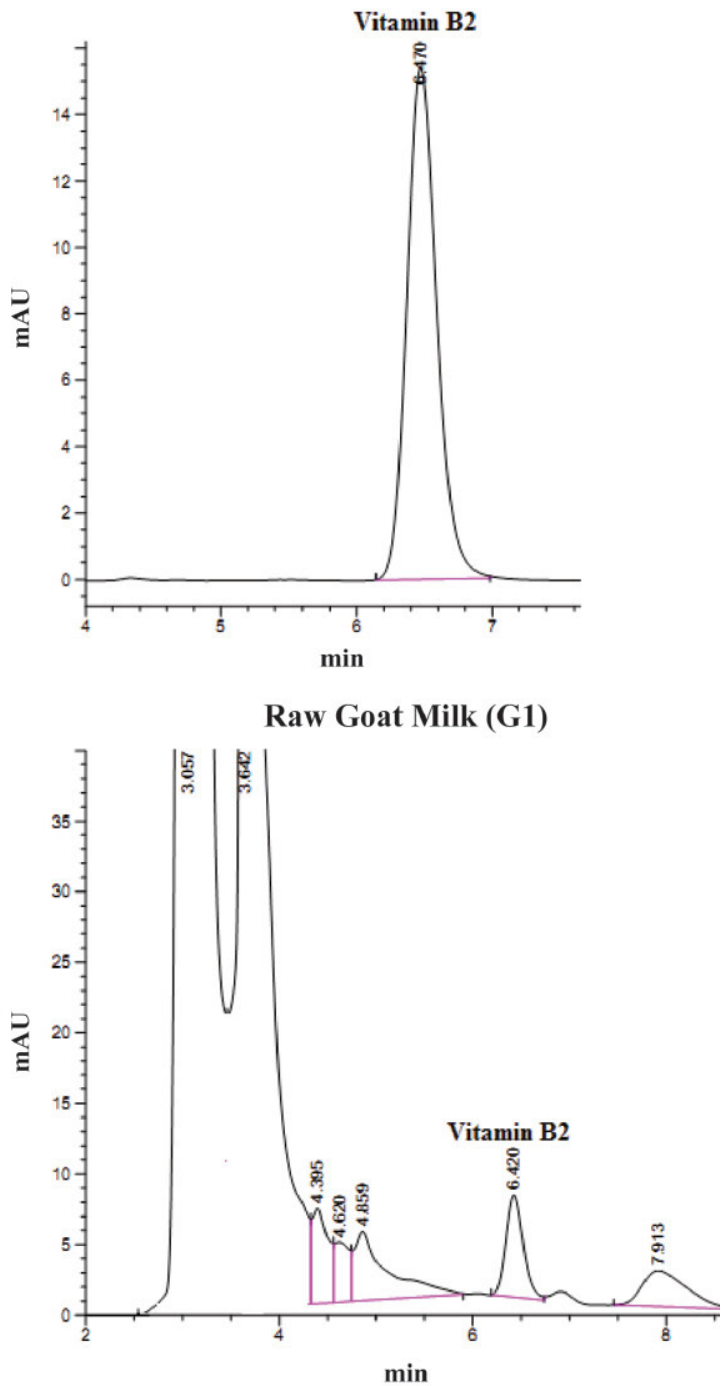

Raw Cow Milk (C1)

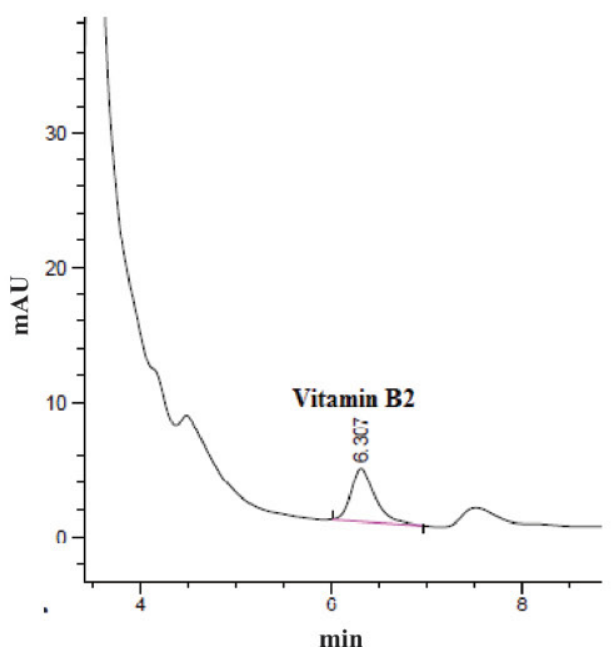

Figure 1. Chromatograms of (a) vitamin $\mathrm{C}$ standard and raw milk samples; and (b) vitamin $\mathrm{B}_{2}$ standard and raw milk samples. Color version available in the online PDF. 


\section{Manipulation Experiment}

The effect of UV light was also investigated by adding vitamin standards at certain levels to milk. Vitamins $\mathrm{A}, \mathrm{B}_{2}, \mathrm{C}$, and $\mathrm{E}$ were added to milk at 4, 3, 40, and $3.5 \mathrm{mg} / \mathrm{L}$, respectively. The same procedures were followed to determine vitamin contents in cow and goat milk samples.

\section{Chemicals and Reagents}

All chemicals, reagents, and vitamin standards used in the HPLC analysis were HPLC grade and obtained from Aldrich Chemical Co. (St. Louis, MO) and Merck KGaA (Darmstadt, Germany).

\section{Statistical Analysis}

Analysis of variance was conducted to determine the differences in vitamin content among milk samples that were applied UV treatment and pasteurization. The ANOVA model is shown in Equation 2:

$$
Y_{i j}=\mu+\alpha_{i}+e_{i j}
$$

where $Y_{i j}$ is the $j$ th observation value in the $i_{\text {th }}$ milk, $\mu$ is the general population mean, $\alpha_{i}$ is the effect of the $i$ th milk, and $e_{i j}$ represents the random error term (Sheskin, 2004). The Tukey honestly significant differences (HSD) test was used for separating means; SPSS for Windows (version 15.0) was used for all statistical analyses (SPSS Inc., 2006).

\section{RESULTS AND DISCUSSION}

\section{Composition of Milk}

The compositions of cow and goat milk are shown in Table 2. Significant differences were observed in cow milk samples in terms of lactic acid, DM, and fat content $(P<0.05)$. However, no significant differences were detected in protein and ash contents of the samples $(P>0.05)$.

The highest DM and fat contents were observed in sample C1. Sample C3 had the highest lactic acid content, whereas the lowest lactic acid content was observed in sample C2. The fat, DM, and lactic acid contents of cow milk samples were 3.05 to $4.20 \%, 11.71$ to $13.21 \%$, and 0.14 to $0.23 \%$, respectively (Table 2 ). These results are consistent with the findings of Amenu et al. (2006) and Ozrenk and Inci (2008). The differences in the composition of cow milk that was obtained at different lactation times may be related to the lactation period, feeding strategy of the cow, and feed composition (Fox and McSweeney, 1998). In a study by Ozrenk and Inci (2008), significant changes in fat, total DM, and protein content of cow milk that was obtained from 12 different locations in Van, Turkey were determined during the lactation period. As expected, they observed that the $\mathrm{DM}$, protein, and fat contents in milk collected in the winter season (January-March) were higher than in milk collected in the summer (JuneAugust). Lindmark-Månsson et al. (2003) investigated seasonal changes in the composition of cow milk obtained from 9 different milk plants in Sweden. They found that the $\mathrm{pH}$ and the protein, lactose, ash, water, and fat-soluble vitamin (except biotin) contents of milk changed significantly through seasons, except that no significant changes in urea, fat, and DM content of milk were observed.

Significant differences were observed in goat milk samples obtained on different days $(P<0.05)$, except in fat content. The highest DM, total protein, ash, and lactic acid contents were observed in sample G2. Sample G3 had the lowest DM and protein content (Table 2). The total DM, lactic acid, and fat content of goat milk samples were 11.38 to $13.79 \%, 0.14$ to $0.19 \%$, and 4.00 to $5.50 \%$, respectively. Güneşer et al. (2010) investigated the chemical composition and FA profiles of 4 different goat breeds in Canakkale. They determined that the lactic acid, DM, and fat contents of Saanen milk were $0.12,10.29$, and $3.25 \%$, respectively. The differences in lactic acid, DM, total protein, and ash contents of goat milk samples can be attributed to changes in milk composition during the lactation period of goats. Thus, changes in goat milk composition based on factors such as breed, feeding, and lactation time, among others, were reported in many studies (Borges et al., 2004; Bhosale et al., 2009; Strzałkowska et al., 2009; Güzeler et al., 2010). Güzeler et al. (2010) identified significant changes in the DM, fat, total protein, and lactose content, energy values, acidity, $\mathrm{pH}$, specific gravity, and sodium content of milk from Saanen $\times$ Kilis goat breeds during the lactation period. Strzałkowska et al. (2009) found a significant increase in density, acidity, and total protein, DM, urea, and FFA content of Polish white improved goat milk during the late-lactation period of goats.

\section{Water-Soluble Vitamins}

Table 3 shows the treatment effect on vitamins $B_{2}$ and $\mathrm{C}$ for each milk sample. The effect of UV light treatment was significant on vitamins $\mathrm{B}_{2}$ and $\mathrm{C}$ in cow milk samples. The reduction in vitamin $\mathrm{C}$ content of milk samples upon UV light treatment is dependent on initial vitamin $\mathrm{C}$ content. No significant difference was observed in the vitamin $\mathrm{C}$ content of raw and pasteur- 
a) Vitamin A Standard
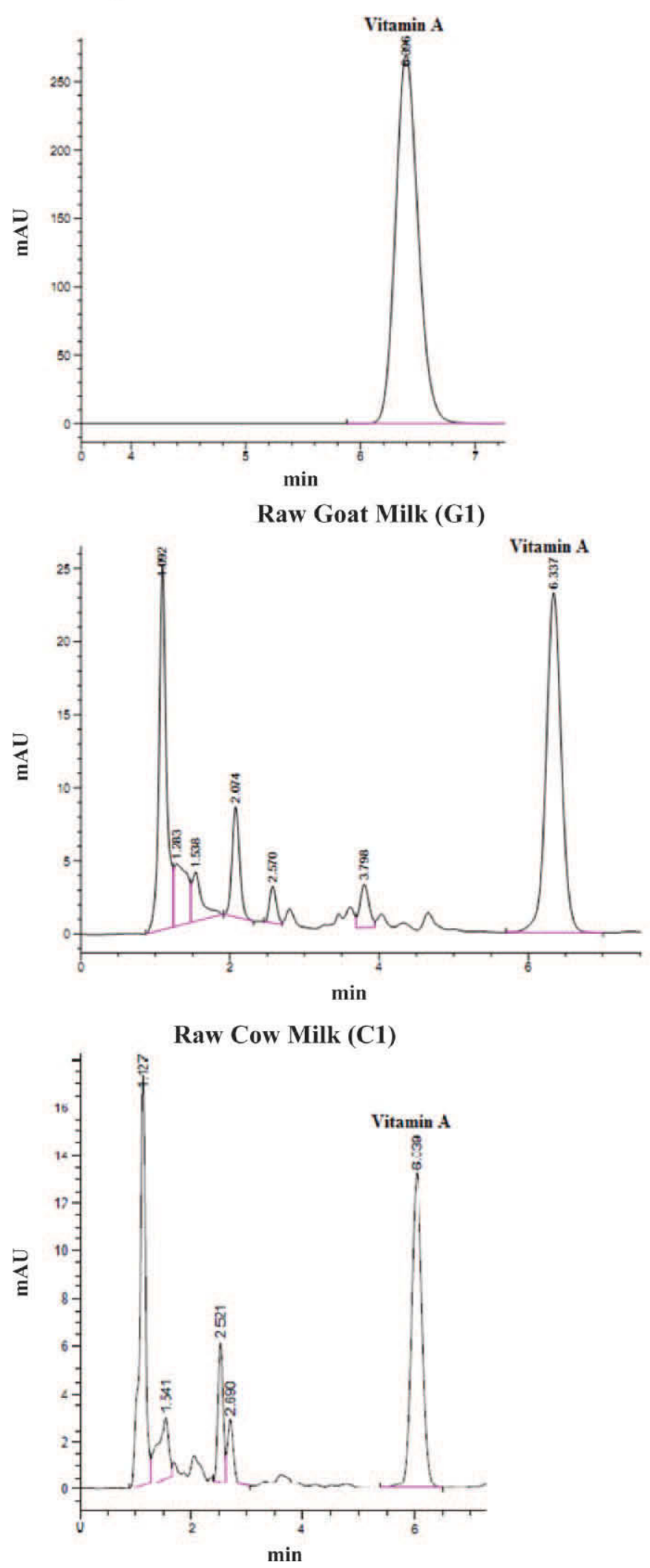

b) Vitamin E Standard

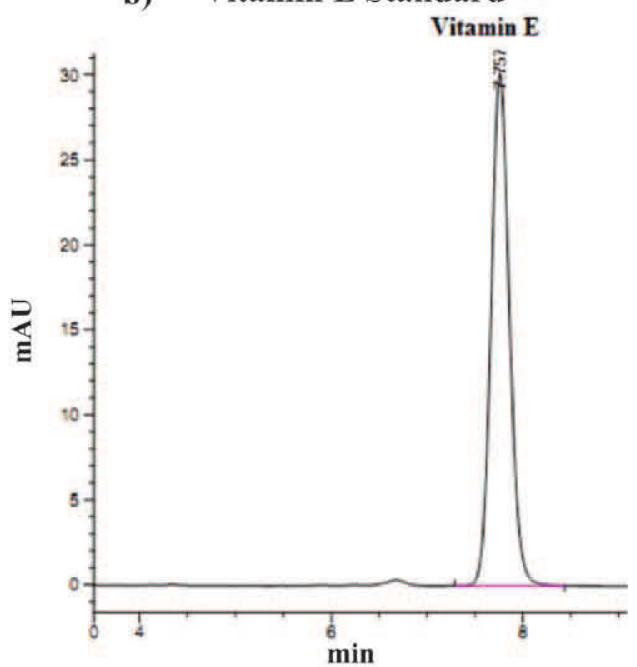

Raw Goat Milk (G1)

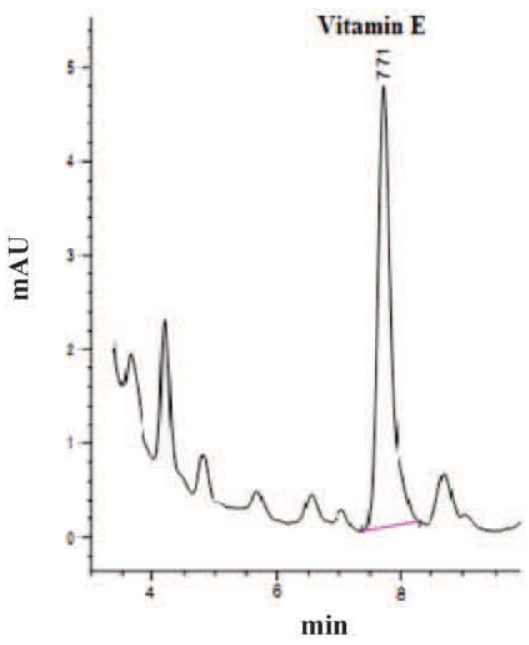

Raw Cow Milk (C1)

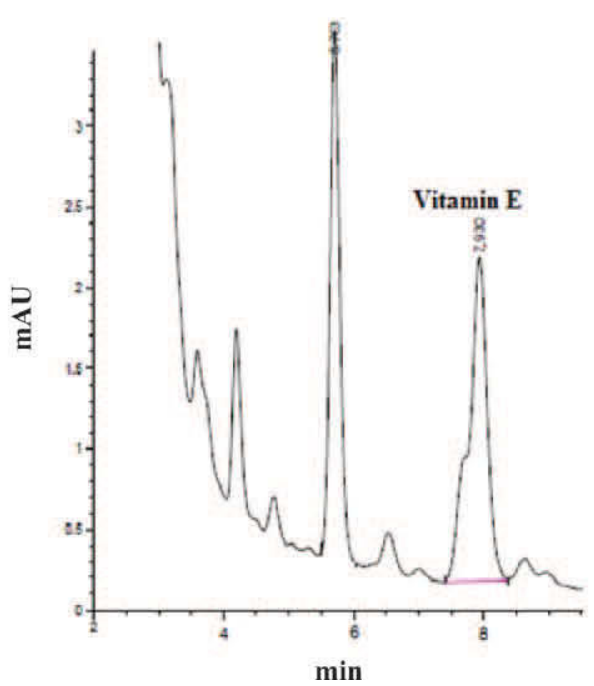

Figure 2. Chromatograms of (a) vitamin A standard and raw milk samples; and (b) vitamin E standard and raw milk samples. Color version available in the online PDF. 
Table 2. Composition of cow and goat milk

\begin{tabular}{|c|c|c|c|c|c|}
\hline \multirow[b]{2}{*}{ Milk sample $^{1}$} & \multicolumn{5}{|c|}{ Chemical property } \\
\hline & Lactic acid (\%) & Total DM (\%) & Fat $(\%)$ & Total protein $(\%)$ & Ash (\%) \\
\hline \multicolumn{6}{|l|}{ Cow milk } \\
\hline $\mathrm{C} 1$ & $0.18 \pm 0.01^{\mathrm{b}}$ & $13.21 \pm 0.03^{\mathrm{a}}$ & $4.20 \pm 0.01^{\mathrm{a}}$ & $1.91 \pm 0.08$ & $0.67 \pm 0.01$ \\
\hline $\mathrm{C} 2$ & $0.14 \pm 0.01^{\mathrm{c}}$ & $11.71 \pm 0.01^{\mathrm{c}}$ & $3.05 \pm 0.05^{\mathrm{b}}$ & $2.13 \pm 0.13$ & $0.64 \pm 0.01$ \\
\hline C3 & $0.23 \pm 0.01^{\mathrm{a}}$ & $11.89 \pm 0.01^{\mathrm{c}}$ & $3.40 \pm 0.01^{\mathrm{b}}$ & $1.89 \pm 0.05$ & $0.64 \pm 0.02$ \\
\hline $\mathrm{C} 4$ & $0.21 \pm 0.01^{\mathrm{ab}}$ & $12.38 \pm 0.08^{\mathrm{b}}$ & $3.37 \pm 0.12^{\mathrm{b}}$ & $2.17 \pm 0.09$ & $0.64 \pm 0.01$ \\
\hline \multicolumn{6}{|l|}{ Goat milk } \\
\hline G1 & $0.16 \pm 0.01^{\mathrm{b}}$ & $12.46 \pm 0.10^{\mathrm{b}}$ & $4.60 \pm 0.40$ & $2.73 \pm 0.02^{\mathrm{b}}$ & $0.85 \pm 0.04^{\mathrm{ab}}$ \\
\hline G2 & $0.19 \pm 0.01^{\mathrm{a}}$ & $13.79 \pm 0.16^{\mathrm{a}}$ & $5.50 \pm 0.50$ & $2.88 \pm 0.02^{\mathrm{a}}$ & $1.00 \pm 0.01^{\mathrm{a}}$ \\
\hline G3 & $0.14 \pm 0.01^{\mathrm{b}}$ & $11.38 \pm 0.01^{\mathrm{c}}$ & $4.00 \pm 0.01$ & $2.52 \pm 0.02^{\mathrm{c}}$ & $0.80 \pm 0.01^{\mathrm{b}}$ \\
\hline
\end{tabular}

${ }^{a-c}$ Means followed by different superscript letters represent significant differences within species for each chemical property $(P<0.05)$

${ }^{1} \mathrm{C} 1, \mathrm{C} 2$, and C3 = cow milk (C1: May 2011; C2: June 2011, C3 and C4: July 2011); G1, G2, and G3 = goat milk (G1: September 2010, G2: October 2010, G3: April 2011).

ized cow milk samples. Three passes of milk in the UV system caused a loss of 78 and $91 \%$ of vitamin $\mathrm{C}$ in the $\mathrm{C} 2$ and $\mathrm{C} 3$ samples, respectively. One-pass UV treatment caused a loss of $74 \%$ of vitamin $\mathrm{C}$ in $\mathrm{C} 1$ milk. Vitamin $\mathrm{C}$ was not detected in $\mathrm{C} 1$ milk after 3,5 , and 7 passes from the system. No significant differences were observed in 3-, 5-, and 7-pass-treated C2 milk samples in terms of vitamin $\mathrm{C}$. The vitamin $\mathrm{B}_{2}$ content of cow milk was decreased by UV light treatment. No significant changes were observed in the content of vitamin $\mathrm{B}_{2}$ in $\mathrm{C} 1, \mathrm{C} 2$, and $\mathrm{C} 3$ samples due to pasteurization. Moreover, no significant differences were observed in the vitamin $\mathrm{B}_{2}$ content of raw, pasteurized, and 1-, 3-, and 5-pass UV light-treated $\mathrm{C} 1$ and $\mathrm{C} 2$ milk samples $(P<0.05)$. Seven-pass UV treatment significantly decreased the vitamin $\mathrm{B}_{2}$ content of $\mathrm{C} 1, \mathrm{C} 2$, and $\mathrm{C} 3$ milk samples by 29,20 , and $31 \%$, respectively (Table 3 ).

Significant differences were observed in the vitamin $\mathrm{C}$ content of raw, pasteurized and UV light-treated goat milk samples $(P<0.05)$. Pasteurization decreased the vitamin $\mathrm{C}$ content at the rate of 35,35 , and $47 \%$ in G1, G2, and G3 milk samples respectively, whereas $75 \%$ (G1), 91\% (G2), and 87\% (G3) vitamin C losses in goat milk samples were observed upon treatment with 1-pass UV light. Vitamin C was not detected in the G3 sample after 3-pass UV light treatment. Similar to cow milk, UV light treatment was more effective in decreasing the vitamin $\mathrm{C}$ content in goat milk when compared with pasteurization. No significant differences were observed in 3-, 5-, and 7-pass UV light treatments of both G1 and G2 for vitamin C. Pasteurization did not show a significant effect on vitamin $\mathrm{B}_{2}$ in goat milk; however, the vitamin $B_{2}$ content in goat milk was decreased by UV light treatment. No loss of vitamin $B_{2}$ content in G1, G2, and G3 milk samples due to pasteurization was observed. The loss of 11 and $7 \%$ of vitamin $B_{2}$ was observed after 3 passes of G1 and G2 milk samples in the UV system, respectively. No significant differ- ences were observed in the vitamin $\mathrm{B}_{2}$ content of raw, pasteurized and 1-, 3-, and 5-pass UV light-treated G3 milk samples. Seven passes from the system decreased the vitamin $\mathrm{B}_{2}$ content of sample $\mathrm{G} 3$ by $23 \%$ (Table 3 ).

Vitamins $\mathrm{C}, \mathrm{B}_{12}, \mathrm{~B}_{6}, \mathrm{~B}_{2}$, and folic acid are lightsensitive, water-soluble vitamins. Vitamin $\mathrm{C}$ highly absorbs UV light at $254 \mathrm{~nm}$; therefore, degradation of vitamin $\mathrm{C}$ by UV light is dependent on the absorption coefficient of foods (Koutchma et al., 2009). The degradation rate of vitamin $\mathrm{C}$ was 8 times faster in clarified apple juice than orange juice due to the greater level of absorbed energy (Koutchma et al., 2009). Koutchma (2010) evaluated the degradation of vitamin C in milk exposed to 2 different UV light sources. The researcher found a $35 \%$ decrease in vitamin $\mathrm{C}$ content caused by a low-pressure mercury UV lamp, whereas 26\% (PUV-1, $31 \mathrm{~J}$ ), 35\% (PUV-2, $344 \mathrm{~J}$ ), and 24\% (PUV-3, $644 \mathrm{~J}$ ) reductions in vitamin $\mathrm{C}$ in milk were observed after treatments with 3 pulsed UV lamps with various energies (PUV-1, 2, and 3). We found a high vitamin $\mathrm{C}$ degradation rate in goat and cow milk. Differences between findings of that study and our results may be attributed to the type of UV light source and UV reactor design, as well as UV procedure. Cakmakçı and Turgut (2005) investigated the effects of various light sources and illumination intensities on degradation of vitamin $\mathrm{C}$ in pasteurized milk during storage. It was found that a fluorescent light source was more effective on loss of vitamin $\mathrm{C}$ in cow milk when compared with a tungsten light source. More vitamin $\mathrm{C}$ was lost in milk upon increasing light intensity. The effects of artificial light on ascorbic acid and oxidized flavor in homogenized and unhomogenized cow milk during 4-d storage were investigated by Smith and Macleod (1955). They found that fluorescent light with $193.75 \mathrm{~lx}$ light intensity decreased the initial vitamin $\mathrm{C}$ content of homogenized milk by $97 \%$ after $4 \mathrm{~d}$ of cold storage. However, the vitamin $\mathrm{C}$ content of milk was decreased 


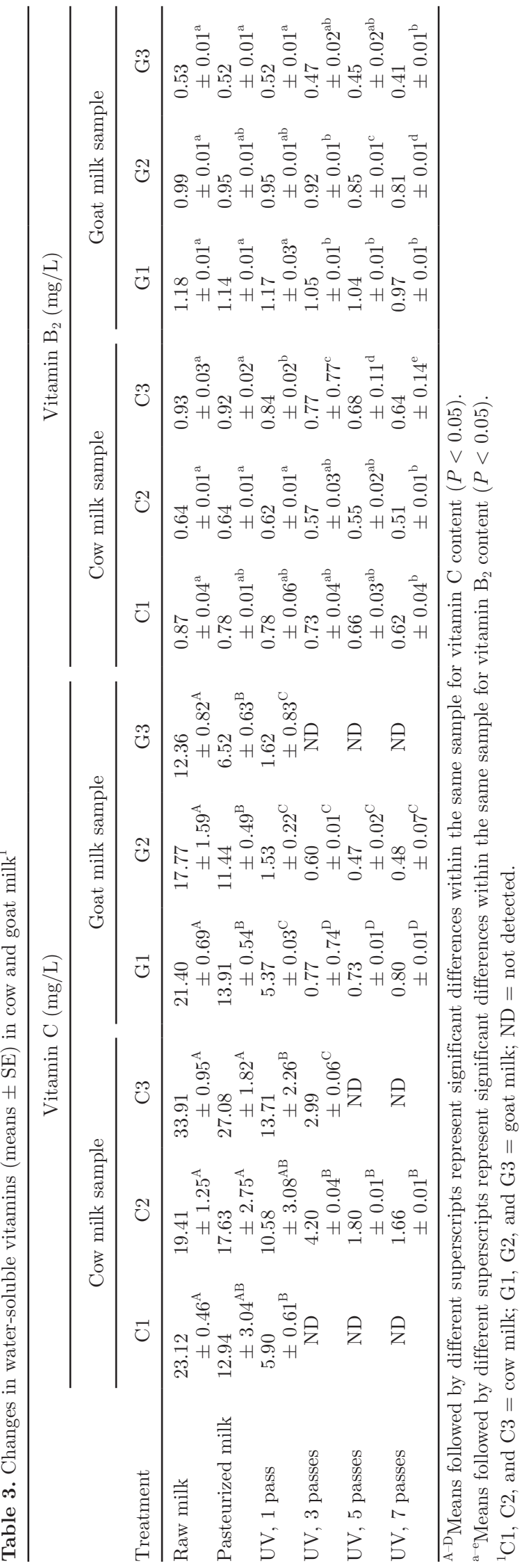

by $87 \%$ under incandescent (tungsten) light with the same light intensity. In another study, a loss of $87 \%$ of vitamin $\mathrm{C}$ in goat milk in a white glass bottle exposed to sunlight for $5 \mathrm{~h}$ was reported (Jandal, 1996).

Vitamin $B_{2}$ is another major vitamin in milk and dairy products. Although vitamin $\mathrm{B}_{2}$ is heat stable, it is more sensitive to light. The degradation of $\mathrm{B}_{2}$ depends on the intensity and wavelength of light (Muñoz et al., 1994; Choe et al., 2005). Vitamin $\mathrm{B}_{2}$ acts as a photosensitizer compound in milk. Photosensitization of riboflavin results in the formation of superoxide anion radicals, singlet oxygen, hydroxy radical, and hydrogen peroxide. These compounds may cause nutrient losses in foods, including degradation of vitamin $\mathrm{A}$ in milk (Choe et al., 2005). Many studies were conducted to determine the degradation rate of vitamin $B_{2}$ in milk under different light conditions (Maniere and Dimick, 1976; Allen and Parks, 1979; Gaylord et al., 1986). Allen and Parks (1979) investigated the degradation kinetics of vitamin $B_{2}$ in milk exposed to fluorescent light with 2,690 lx light intensity. The same researchers found that the degradation kinetics of vitamin $B_{2}$ in whole and skim milk were followed the first-order kinetics (Allen and Parks, 1979). It was also found that the vitamin $\mathrm{B}_{2}$ contents of whole and skim milk were decreased by 87.9 and $76.12 \%$, respectively, when $32 \mathrm{~h}$ of fluorescent light was applied. Maniere and Dimick (1976) reported $90.4 \%$ loss in the vitamin $\mathrm{B}_{2}$ amount in homogenized milk that was exposed to fluorescent light at 2,150 lx intensity for $48 \mathrm{~h}$ at $7^{\circ} \mathrm{C}$. Gaylord et al. (1986) evaluated the effect of milk fat, milk solid, and light intensity on the stability of $\mathrm{B}_{2}$. It was found that the stability of vitamin $\mathrm{B}_{2}$ increased by increasing the fat content of milk. They found that the loss of vitamin $\mathrm{B}_{2}$ in whole milk, $2 \%$ fat milk, and skim milk was 55 , 64 , and $70 \%$, respectively, after $48 \mathrm{~h}$ of fluorescent light exposure at 1,614 lx. Saffert et al. (2006) reported 33\% loss in vitamin $\mathrm{B}_{2}$ in pasteurized whole milk (3\% fat) that was stored under fluorescent light with $1,700 \mathrm{~lx}$ intensity at $8^{\circ} \mathrm{C}$ in clear 1-L polyethylene terephthalate bottles for $10 \mathrm{~d}$.

\section{Fat-Soluble Vitamins}

Changes in vitamin $\mathrm{A}$ and $\mathrm{E}$ in cow and goat milk samples are shown in Table 4. The effect of UV light treatment was significant on vitamin $\mathrm{A}$ and $\mathrm{E}$ in cow milk $(P<0.05)$. It was found that several passes of milk in the UV light unit decreased the vitamin A content of cow milk. However, pasteurization did not show a significant effect on vitamin A in cow milk.

No significant differences were observed in vitamin A content of raw, pasteurized, and 1- and 3-pass UV light-treated C1, C2, and C3 milk samples. Therefore, 
pasteurization and UV light treatment up to 3 passes had the same effect on degradation of vitamin $\mathrm{A}$ in cow milk. Although no loss in vitamin A content in $\mathrm{C} 1$, $\mathrm{C} 2$, and $\mathrm{C} 3$ milk samples due to pasteurization was observed, a 30,32 , and $32 \%$ decrease in vitamin $\mathrm{A}$ in $\mathrm{C} 1$, $\mathrm{C} 2$, and $\mathrm{C} 3$ milk samples, respectively, was observed after 7 passes. Ultraviolet light treatment decreased the vitamin $\mathrm{E}$ content in cow milk, but pasteurization did not show a significant effect on vitamin $\mathrm{E}$ in cow milk. No significant differences were observed in the vitamin E content of raw, pasteurized, 1-pass UV-treated C1, C2, and C3 milk samples. Seven-pass UV treatment decreased the vitamin $\mathrm{E}$ content of samples $\mathrm{C} 1, \mathrm{C} 2$, and $\mathrm{C} 3$ by 66,69 , and $72 \%$, respectively.

The effect of UV light treatment was significant on vitamin $\mathrm{A}$ and $\mathrm{E}$ in goat milk $(P<0.05$; Table 4$)$. It was found that 7-pass UV light treatment had an adverse effect on the vitamin A content in goat milk, but pasteurization did not have a significant effect on vitamin A in goat milk. No significant differences were observed in the vitamin A content of raw, pasteurized, and 1-pass and 3-pass UV light-treated G1, G2, and G3 milk samples. It was found that 7-pass UV treatment decreased the vitamin A content of G1 and G2 samples by 19 and $30 \%$, respectively, and $29 \%$ of vitamin A in G3 milk was lost by 7 passes. Similar to cow milk, the extent to which the vitamin $\mathrm{E}$ content of goat milk was affected by UV light treatment depended on the initial vitamin E content of the goat milk. Pasteurization did not cause any significant decrease in vitamin $\mathrm{E}$ content of G2 and G3 samples. The vitamin E content of G1 was decreased by pasteurization by $22 \%$. It was found that the vitamin E content of G1 and G3 milk samples was reduced by 24 and $66 \%$, respectively, after 7 passes in the system (Table 4).

Vitamin A is a derived form of carotenoids (principally $\beta$-carotene) and found in milk naturally as retinyl esters. Vitamin A, as well as riboflavin, is photosensitive in milk. Therefore, when milk is exposed to light, degradation in vitamin A occurs by photoisomerization (deMan, 1981; Miller et al., 2007). Degradation of vitamin A in milk due to light exposure was also investigated in several studies (deMan, 1981; Gaylord et al., 1986; Chapman et al., 1998; Whited et al., 2002). deMan (1981) investigated the loss of vitamin A in whole, $2 \%$ fat milk and skim milk exposed to fluorescent light with $2,200 \mathrm{~lx}$ intensity for $48 \mathrm{~h}$ at refrigerated temperatures. The researcher reported the loss of 32.3, 23.6, and $95.8 \%$ of vitamin A in whole milk, $2 \%$ fat milk, and skim milk, respectively, after $30 \mathrm{~h}$ of exposure. In another study (Gaylord et al., 1986), the losses by 43 , 47 , and $55 \%$ in vitamin $\mathrm{A}$ in whole milk, $2 \%$ fat milk, and skim milk after 48-h exposure to fluorescent light with 1,614 lx intensity were reported. Chapman et al.

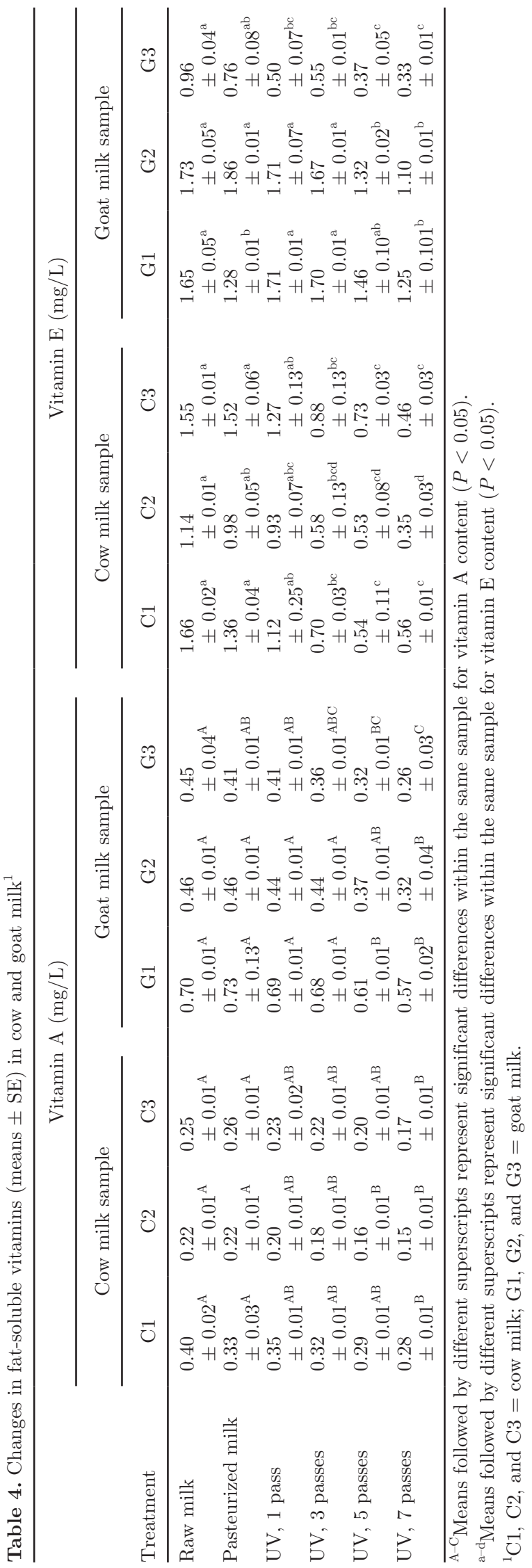


Table 5. Changes in water- and fat-soluble vitamins (means $\pm \mathrm{SE})$ in manipulated milk $(\mathrm{C} 4 ; \mathrm{mg} / \mathrm{L}$ of milk)

\begin{tabular}{lcccc}
\hline Milk sample & Vitamin A & Vitamin $B_{2}$ & Vitamin C & Vitamin E \\
\hline Raw milk (C4) & $0.15 \pm 0.01^{\mathrm{f}}$ & $1.76 \pm 0.05^{\mathrm{c}}$ & $16.63 \pm 0.04^{\mathrm{d}}$ & $0.80 \pm 0.01^{\mathrm{g}}$ \\
Vitamin-added raw milk & $3.41 \pm 0.01^{\mathrm{a}}$ & $4.90 \pm 0.01^{\mathrm{a}}$ & $61.15 \pm 0.71^{\mathrm{a}}$ & $3.52 \pm 0.06^{\mathrm{a}}$ \\
Vitamin-added pasteurized milk & $2.94 \pm 0.01^{\mathrm{b}}$ & $5.02 \pm 0.27^{\mathrm{a}}$ & $55.92 \pm 0.97^{\mathrm{b}}$ & $3.27 \pm 0.02^{\mathrm{b}}$ \\
UV, 1 pass & $2.93 \pm 0.01^{\mathrm{b}}$ & $4.85 \pm 0.29^{\mathrm{a}}$ & $49.99 \pm 0.89^{\mathrm{c}}$ & $2.87 \pm 0.01^{\mathrm{c}}$ \\
UV, 3 passes & $2.89 \pm 0.01^{\mathrm{c}}$ & $4.70 \pm 0.19^{\mathrm{a}}$ & $8.96 \pm 0.01^{\mathrm{e}}$ & $2.70 \pm 0.02^{\mathrm{d}}$ \\
UV, 5 passes & $2.86 \pm 0.01^{\mathrm{d}}$ & $4.57 \pm 0.22^{\mathrm{ab}}$ & $1.65 \pm 0.01^{\mathrm{f}}$ & $2.41 \pm 0.04^{\mathrm{e}}$ \\
UV, 7 passes & $2.57 \pm 0.01^{\mathrm{e}}$ & $3.58 \pm 0.06^{\mathrm{b}}$ & $1.48 \pm 0.01^{\mathrm{f}}$ & $1.57 \pm 0.01^{\mathrm{f}}$ \\
\hline
\end{tabular}

${ }^{\mathrm{a}-\mathrm{g}}$ Means followed by different superscripts represent significant differences in the same vitamin $(P<0.05)$.

(1998) evaluated vitamin A degradation and light oxidized flavor development in chocolate milk exposed to fluorescent light for $14 \mathrm{~h}$ at $4^{\circ} \mathrm{C}$. They found $1.40 \%$ of vitamin A losses in chocolate colored and flavored milk in contrast to $24.24 \%$ loss in unflavored $2 \%$ fat milk. The degradation of vitamin $\mathrm{A}$ and light oxidized flavor defect in milk at different fluorescent light intensities were investigated in another study by Whited et al. (2002). They reported that vitamin A content was reduced by $29 \%$ in reduced fat milk and by $49 \%$ in nonfat milk after 16-h exposure to 2,000 lx fluorescent light. They also reported that the vitamin A content of whole milk, reduced-fat milk, and nonfat milk was reduced by 0 , 24 , and $32 \%$, respectively, after 16 -h exposure to 1,000 lx. Saffert et al. (2008) determined the effect of package light transmittance and fluorescent light intensity on vitamin $\mathrm{A}, \mathrm{B}_{2}$, and $\mathrm{D}_{3}$ content in UHT milk. They reported a 66,79 , and $88 \%$ loss in vitamin $\mathrm{A}$ in milk stored in clear-transparent polyethylene terephthalate bottles after $12 \mathrm{wk}$ of storage at 700, 1,700, and 3,000 lx at $23^{\circ} \mathrm{C}$, respectively. When the results of previous studies were examined, the vitamin A degradation rate in milk varied, depending on the duration and intensity of light exposure. Relatively lower vitamin A degradation rate in milk exposed to 1-pass UV light (12.6 J/ $\mathrm{mL}$ doses for cow milk; $11.72 \mathrm{~J} / \mathrm{mL}$ doses for goat milk) at $254 \mathrm{~nm}$ was observed in the present study. It was observed that 1-pass UV light treatment had the same degradation effect as pasteurization did on vitamin A in both cow and goat milk. However, further detailed studies are essential to determine the effects of UV light on fat-soluble vitamins in milk and dairy products.

\section{Manipulation Experiment}

Changes in vitamins $\mathrm{A}, \mathrm{B}_{2}, \mathrm{C}$, and $\mathrm{E}$ in the manipulated cow milk sample (C4) are shown in Table 5. The effect of UV light treatment on vitamin $\mathrm{C}$ in milk was found to be significant $(P<0.05)$. No significant differences were observed among vitamin-added raw, pasteurized, and 1-pass, 3-pass, and 5-pass UV light-treated milk samples for vitamin $\mathrm{B}_{2}(P>0.05)$.
Seven-pass UV treatment significantly decreased the vitamin $\mathrm{B}_{2}$ content of milk; $27 \%$ of vitamin $\mathrm{B}_{2}$ loss in milk was observed after 7-pass UV treatment. On the other hand, it was determined that UV treatment decreased vitamin $\mathrm{C}$ content of milk more than the pasteurization process. Nine percent of vitamin $\mathrm{C}$ in milk was lost upon pasteurization; however, $19 \%$ of vitamin $\mathrm{C}$ was lost by 1-pass UV light treatment. A significant decrease in vitamin $\mathrm{C}$ content of milk was also observed by increasing the application dose of UV treatment $(P$ $<0.05$ ). Five-pass UV treatment decreased the content of vitamin $\mathrm{C}$ in milk by approximately $98 \%$.

The effects of UV and heat treatments were significant on vitamins $\mathrm{A}$ and $\mathrm{E}$ in milk. A significant decrease in vitamin A content of milk was also observed by increasing the application dose of UV $(P<0.05)$. Although pasteurization decreased the content of vitamin A by 14\%, 3-, 5-, and 7-pass UV treatments decreased the content of vitamin A by 15,16 , and $25 \%$, respectively (Table 5). In addition, significant differences were observed between pasteurized and UV-treated milk samples in terms of vitamin $\mathrm{E}$ content. The 1-pass UV-treated milk sample had a lower vitamin E content than the vitamin-added raw and pasteurized milk samples $(P<0.05)$. Pasteurization decreased vitamin $\mathrm{E}$ by 7\%. The 1-, 3-, 5-, and 7-pass UV treatments decreased vitamin $\mathrm{E}$ in milk by $18,23,32$, and $55 \%$, respectively. This result shows that UV treatment was more effective than the pasteurization process at degrading vitamin E. Hence, a significant decrease in vitamin E content of milk was also observed by increasing the application dose of UV treatment $(P<0.05$; Table 5$)$.

\section{CONCLUSIONS}

The amounts of water- and fat-soluble vitamins in milk were affected by pasteurization and UV treatment. The ranges of vitamin losses by heat and UV light treatment of cow and goat milk samples are summarized in Table 6. One-pass UV treatment decreased vitamin A, $\mathrm{B}_{2}, \mathrm{C}$, and $\mathrm{E}$ contents of cow milk by 8 to $13 \%, 3$ to $10 \%, 45$ to $74 \%$, and 16 to $33 \%$, respectively. Vitamin 
Table 6. Ranges for vitamin losses in milk samples ${ }^{1}$ by heat and UV light treatments

\begin{tabular}{|c|c|c|c|c|c|c|c|c|}
\hline \multirow[b]{2}{*}{ Treatment } & \multicolumn{8}{|c|}{ Loss of vitamin in milk (\%) } \\
\hline & Cow milk & Goat milk & Cow milk & Goat milk & Cow milk & Goat milk & Cow milk & Goat milk \\
\hline Pasteurization & $0-17$ & $0-8.8$ & $1-10$ & $1.8-4.0$ & $9.0-44$ & $35-47$ & $1.9-14$ & $0-22.4$ \\
\hline UV, 1 pass & $8.0-13$ & $1.0-9.0$ & $3.0-10$ & $1.0-2.0$ & $45-74$ & $75-91$ & $16-33$ & $1.0-48$ \\
\hline UV, 3 passes & $12-20$ & $2.85-20$ & $10.9-17.2$ & $11-11.3$ & $78.4-91.2$ & $91.2-96.6$ & $43.2-57.8$ & $3.5-42.7$ \\
\hline
\end{tabular}

${ }^{1}$ The milk samples are cow milk (C1, C2, and C3) and goat milk (G1, G2, and G3) samples.

$\mathrm{A}, \mathrm{B}_{2}, \mathrm{C}$, and $\mathrm{E}$ contents in goat milk were decreased by 1 -pass UV treatment by 1 to $9 \%, 1$ to $2 \%, 75$ to $91 \%$, and 1 to $48 \%$, respectively. Specifically, vitamins $\mathrm{C}$ and $\mathrm{E}$ are more sensitive to UV light. Ultraviolet light sensitivities for cow and goat milk samples were in the following order: vitamin $\mathrm{C}>$ vitamin $\mathrm{E}>$ vitamin $\mathrm{A}>$ vitamin $\mathrm{B}_{2}$. The amount of vitamin losses in milk depends on the number of passes of milk through the UV system, initial amount of vitamin in milk, and the intensity of UV light application. Before recommending this nonthermal technology as an alternative to heat treatment, more studies are needed on the effects of UV light on the nutritional value of milk and dairy products.

\section{ACKNOWLEDGMENTS}

This study was funded by The Scientific Research Fund of Canakkale Onsekiz Mart University (Canakkale, Turkey; Project No. 2010/04). Funding for the UV light instrument was provided by The Scientific and Technological Council of Turkey (TUBITAK, Ankara Turkey; Project No. 108O257). The authors are grateful to Yusuf Köprülü (Gentra Insaat ve Ticaret Ltd. Sti., Istanbul, Turkey) for designing the UV instrument.

\section{REFERENCES}

Allen, C., and O. W. Parks. 1979. Photodegradation of riboflavin in milks exposed to fluorescent light. J. Dairy Sci. 62:1377-1379.

Altic, L. C., T. M. Rowe, and R. Grant. 2007. UV light inactivation of Mycobacterium avium subsp. paratuberculosis in milk as assessed by FASTPlaqueTB phage assay and culture. Appl. Environ. Microbiol. 73:3728-3733.

Amenu, B., T. Cowan, H. Deeth, and R. Moss. 2006. Impact of feeding system and season on milk composition and Cheddar cheese yield in a subtropical environment. Aust. J. Exp. Agric. 46:299-306.

Asadullah, Khair-un-Nisa, O. M. Tarar, S. A. Ali, K. Jamil, and A. Begum. 2010. Study to evaluate the impact of heat treatment on water soluble vitamins in milk. J. Pak. Med. Assoc. 60:909-912.

Bendicho, S., A. Espachs, J. Arántegui, and O. Martín. 2002. Effect of high intensity pulsed electric fields and heat treatments on vitamins of milk. J. Dairy Res. 69:113-123.
Bhosale, S. S., P. A. Kahate, K. Kamble, V. M. Thakare, and S. G. Gubbawar. 2009. Effect of lactation on physico-chemical properties of local goat milk. Vet. World 2:17-19.

Bintsis, T., E. Litopoulou-Tzanetaki, and R. K. Robinson. 2000. Existing and potential applications of ultraviolet light in food industry-A critical review. J. Sci. Food Agric. 80:637-645.

Borges, C. H. P., P. R. C. Cordeiro, and S. Bresslau. 2004. Seasonal variation of goat milk composition and somatic cell count in the Southeastern region of Brazil. S. Afr. J. Anim. Sci. 34(Suppl. 1):32-35.

Bradley, J. R. L., J. E. Arnold, D. M. Barbano, R. G. Semerad, D. E. Smith, and B. K. Vines. 1992. Chemical and physical methods. Pages 433-531 in Standard Methods for the Examination of Dairy Products. R. T. Marshall, ed. American Public Health Association, Washington, DC.

Cakmakçı, S., and T. Turgut. 2005. Influence of different light sources, illumination intensities and storage times on the vitamin $\mathrm{C}$ content in pasteurized milk. Turk. J. Vet. Anim. Sci. 29:1097-1100.

Caminiti, I. M., I. Palgan, A. Muñoz, F. Noci, P. Whyte, D. J. Morgan, D. A. Cronin, and J. G. Lyng. 2012. The effect of ultraviolet light on microbial inactivation and quality attributes of apple juice. Food Bioprocess Technol. 5:680-686. http://dx.doi.org/10.1007/ s11947-010-0365-x.

Chapman, K. W., L. C. Rosenberry, D. K. Bandler, and K. J. Boor 1998. Light-oxidized flavor development and vitamin A degradation in chocolate milk. J. Food Sci. 63:930-934.

Choe, E., R. Huang, and D. B. Min. 2005. Chemical reactions and stability of riboflavin in foods. J. Food Sci. 70:R28-R36.

deMan, J. M. 1981. Light-induced destruction of vitamin A in milk. J. Dairy Sci. 64:2031-2032.

Donaghy, J., M. Keyser, J. Johnston, F. P. Cilliers, P. A. Gouws, and M. T. Rowe. 2009. Inactivation of Mycobacterium avium ssp. paratuberculosis in milk by UV treatment. Lett. Appl. Microbiol. 49:217-221.

Engin, B., O. Güneșer, and Y. Karagül-Yüceer. 2009. Ultraviyole 1şınlarının sütün mikrobiyel özellikleri üzerine etkisi (Effect of ultraviolet light on microbiological properties of milk). Gida 34:303-308.

Engin, B., and Y. Karagul Yuceer. 2012. Effects of ultraviolet light and ultrasound on microbial quality and aroma-active components of milk. J. Sci. Food Agric. 92:1245-1252. http://dx.doi. org $/ 10.1002 /$ jsfa.4689.

Fox, P. F., and P. L. H. McSweeney. 1998. Dairy Chemistry and Biochemistry. Blackie Academic \& Professional, London, UK.

Franz, C. M. A. P., I. Specht, G.-S. Cho, V. Graef, and M. R. Stahl. 2009. UV-C-inactivation of microorganisms in naturally cloudy apple juice using novel I-inactivation equipment based on dean vortex technology . Food Contr. 20:1103-1107.

Fredericks, I. N., M. du Toit, and M. Krügel. 2011. Efficacy of ultraviolet radiation as an alternative technology to inactivate microorganisms in grape juices and wines. Food Microbiol. 28:510-517.

Gachovska, T. K., S. Kumar, H. Thippareddi, J. Subbiah, and F. Williams. 2008. Ultraviolet and pulsed electric field treatments have 
additive effect on inactivation of E. coli in apple juice. J. Food Sci. 73:M412-M417.

Gaylord, A. M., J. J. Warthesen, and D. E. Smith. 1986. Influence of milk fat, milk solids, and light intensity on the light stability of vitamin A and riboflavin in lowfat milk. J. Dairy Sci. 69:2779-2784.

Geveke, D. J. 2008. UV inactivation of E. coli in liquid egg white. Food Bioproc. Technol. 1:201-206.

Guerrero-Beltrán, J. A., J. Welti-Chanes, and G. V. Barbosa-Cánovas. 2009. Ultraviolet-C light processing of grape, cranberry and grapefruit juices to inactivate Saccharomyces cerevisiae. J. Food Process Eng. 32:916-932. http://dx.doi.org/10.1111/j.17454530.2008.00253.x.

Güneșer, O., Y. Karagül-Yüceer, and A. Konyalı. 2010. Canakkale'de yetiştiriciliği yapılan bazı keçi ırklarına ait sütlerin yağ asidi profili. Pages 359-365 in Proc. Ulusal Keçicilik Kongresi, Çanakkale, Türkiye.

Güzeler, N., D. Say, and A. Kaçar. 2010. Compositional changes of Saanen $\times$ Kilis goats' milk during lactation. Gida 35:325-330.

Holmes, A. D., H. G. Lindquist, C. P. Jones, and A. W. Wertz. 1945. Effect of high-temperature-short-time pasteurization on the ascorbic acid, riboflavin and thiamin content of milk. J. Dairy Sci. 28:29-33.

Jandal, J. M. 1996. Factors affecting ascorbic acid content and keeping quality of Shammi goat milk. Small Rumin. Res. 21:121-125.

Keyser, M., I. A. Müller, F. P. Cilliers, W. Nel, and P. A. Gouws. 2008. Ultraviolet radiation as a non-thermal treatment for the inactivation of microorganisms in fruit juice. Innovative Food Sci. Emerg. Technol. 9:348-354.

Kondyli, E., M. C. Katsiari, and L. P. Voutsinas. 2007. Variations of vitamin and mineral contents in raw goat milk of the indigenous Greek breed during lactation. Food Chem. 100:226-230.

Koutchma, T. 2009. Advances in ultraviolet light technology for nonthermal processing of liquid foods. Food Bioproc. Technol. 2:138 155 .

Koutchma, T. 2010. UV irradiation improves safety of foods and beverages. Proc. SPIE 7789, 77890H, Newsroom. Accessed Nov. 15, 2011. http://spie.org/ $42390 . x m l ?$ ArticleID $=x 42390$.

Koutchma, T., L. J., Forney, and C. I. Moraru. 2009. UV processing effects on quality of foods. Pages 103-123 in Ultraviolet Light in Food Technology: Principles and Applications. T. Koutchma, L. J. Forney, and C. I. Moraru, ed. CRC Press, Boca Raton, FL.

Lavigne, C., J. A. Zee, R. E. Simard, and B. Béliveau. 1989. Effect of processing and storage conditions on fate of vitamins $\mathrm{B}_{1}, \mathrm{~B}_{2}, \mathrm{C}$ and on the shelf life goat's milk. J. Food Sci. 54:30-34.

Lewis, M. J. 2003. Improvements in the pasteurization and sterilization of milk. Pages 81-100 in Dairy Processing: Improving Quality. G., Smith ed. Woodhead Publishing, CRC Press. Boca Raton, FL.

Lindmark-Månsson, H., R. Fondén, and H. E. Pettersson. 2003. Composition of Swedish dairy milk. Int. Dairy J. 13:409-425.

Lopez-Malo, A., and E. Palou. 2005. Ultraviolet light and food preservation. Pages 405-421 in Novel Food Processing Technologies. G. V. Barbosa-Canovas, M. S. Tapia, and M. P. Cano, ed. Marcel Dekker, New York, NY.

Maniere, F. Y., and P. S. Dimick. 1976. Effect of fluorescent light on repartition of riboflavin in homogenized milk. J. Dairy Sci. 59:2019-2023.

Matak, K. E., J. J. Churey, R. W. Worobo, S. S. Sumner, E. Hovingh, C. R. Hackney, and M. D. Pierson. 2005. Efficacy of UV light for the reduction of Listeria monocytogenes in goat's milk. J. Food Prot. 68:2212-2216.

Miller, D. G., J. K. Jarvis, and L. D. McBean. 2007. Handbook of Dairy Food and Nutrition. 3rd ed. CRC Press, Taylor \& Francis Group, Boca Raton, FL.
Moltó-Puigmartí, C., M. Permanyer, A. I. Castellote, and M. C. López-Sabater. 2011. Effects of pasteurisation and high-pressure processing on vitamin $\mathrm{C}$, tocopherols and fatty acids in mature human milk. Food Chem. 124:697-702.

Muñoz, A., R. Ortiz, and M. A. Murcia. 1994. Determination by HPLC of changes in riboflavin levels in milk and nondairy imitation milk during refrigerated storage. Food Chem. 49:203-206.

NEN (The Netherlands Standardization Institute). 1969. Netherlands Standard 3059, butyrometric determination of the fat content of cheese (Gerber-Van Gulik method). Neth. Milk Dairy J. 23:214220

Oamen, E. E., A. P. Hansen, and K. R. Swartzel. 1989. Effect of ultrahigh temperature steam injection processing and aseptic storage on labile water-soluble vitamins in milk. J. Dairy Sci. 72:614-619.

Ozrenk, E., and S. S. Inci. 2008. The effect of seasonal variation on the composition of cow milk in Van province. Pak. J. Nutr. 7:161-164.

Raynal-Ljutovac, K., A. Pirisi, R. de Crémoux, and C. Gonzalo. 2007. Somatic cells of goat and sheep milk: Analytical, sanitary, productive and technological aspects. Small Rumin. Res. 68:126-144.

Reinemann, D. J., P. Gouws, T. Cilliers, K. Houck, and J. R. Bishop. 2006. New methods for UV treatment of milk for improved food safety and product quality. Paper number 066088 in Proc. ASABE Annual International Meeting, Portland, OR. Am. Soc. Agric. Biol. Eng., St. Joseph, MI.

Romeu-Nadal, M., S. Morera-Pons, A. I. Castellote, and M. C. LópezSabater. 2006. Rapid high-performance liquid chromatographic method for vitamin $\mathrm{C}$ determination in human milk versus an enzymatic method. J. Chromatogr. B Analyt. Technol. Biomed. Life Sci. 830:41-46.

Saffert, A., G. Pieper, and J. Jetten. 2006. Effect of package light transmittance on the vitamin content of pasteurized whole milk. Packag. Technol. Sci. 19:211-218.

Saffert, A., G. Pieper, and J. Jetten. 2008. Effect of package light transmittance on vitamin content of milk. Part 2: UHT whole milk. Packag. Technol. Sci. 21:47-55.

Sheskin, D. J. 2004. Handbook of Parametric and Nonparametric Statistical Procedures. Chapman and Hall-CRC Press, New York, NY.

Sierra, I., and C. Vidal-Valverde. 2001. Vitamin $\mathrm{B}_{1}$ and $\mathrm{B}_{6}$ retention in milk after continuous-flow microwave and conventional heating at high temperatures. J. Food Prot. 64:890-894.

Smith, A. C., and P. MacLeod. 1955. The effect of artificial light on milk in cold storage. J. Dairy Sci. 38:870-874.

Smith, W. L., M. C. Lagunas-Solar, and J. S. Cullor. 2002. Use of pulsed ultraviolet laser light for the cold pasteurization of bovine milk. J. Food Prot. 65:1480-1482.

SPSS Inc. 2006. SPSS Professional Statistics 17.0. SPSS Inc., Chicago, IL.

Strzałkowska, N., A. Jóźwik, E. Bagnicka, J. Krzyżewski, K Horbańczuk, B. Pyzel, and O. J. Horbańczuk. 2009. Chemical composition, physical traits and fatty acid profile of goat milk as related to the stage of lactation. Anim. Sci. Pap. Rep. 27:311-320.

Uysal Pala, C., and A. Kirca Toklucu. 2011. Effect of UV-C light on anthocyanin content and other quality parameters of pomegranate juice. J. Food Compost. Anal. 24:790-795.

Whited, L. J., B. H. Hammond, K. W. Chapman, and K. J. Boor. 2002. Vitamin A degradation and light-oxidized flavor defects in milk. J. Dairy Sci. 85:351-354.

Zahar, M., and D. E. Smith. 1990. Vitamin a quantification in fluid dairy products: rapid method for vitamin a extraction for high performance liquid chromatography. J. Dairy Sci. 73:3402-3407. 